\title{
OPTIMALITY THEORY AND HISTORICAL PHONOLOGY: AN EXAMPLE FROM NASAL HARMONY IN MUNDURUKÚ
}

\author{
Gessiane PICANÇO*
}

- ABSTRACT: This paper offers an account of diachronic changes in nasal harmony in Mundurukú, a Tupian language from Brazil. It attempts to show that the Optimality Theory provides new ways of accounting for sound change, other than constraint re-ranking. A comparison of Mundurukú and Kuruaya's modern systems points out that the source system, Proto-Mundurukú, had similar properties to those currently observed in Kuruaya. In particular, nasal spread targets were voiced stops and sonorants, whereas voiceless obstruents were transparent. This system was developed into another in Pre-Mundurukú, because new contrasts were introduced in the language, turning obstruents into opaque segments, thus blocking nasalization. Formal OT account of both cases relies on restricting harmony constraints, as shown by the relative chronology that gave rise to Mundurukú's modern system. In addition, this study discusses the consequences of this change to synchronic grammar, and how it explains the process' irregularities.

- KEYWORDS: Sound change. Nasal harmony. Optimality theory. Historical phonology. Mundurukú.

\section{Introduction}

Generative phonology has dealt with sound change in terms of rule addition, simplification, reordering and loss (KIPARSKY, 1982). With the advent of constraintbased theories, such as the Optimality Theory (PRINCE; SMOLENSKY, 1993; MCCARTHY; PRINCE, 1993), historical phonology has gained a new angle. The Optimality Theory (hereafter OT) usually explains sound change as the result of constraint re-ranking. However, this paper shows that re-ranking is not the only way to account for sound change; constraints may also become more restrictive, forcing further adaptations of the phonological system, leading to changes. This will be illustrated by an example of sound change in Mundurukú's (Tupí) historical phonology, namely, nasal harmony. ${ }^{1}$

* UFPA - Universidade Federal do Pará. Faculdade de Letras. Belém - Pará - Brasil. 66093-005 - picanco.g@ hotmail.com

1 This article is adapted from my doctoral dissertation, "Mundurukú: Phonetics, Phonology, Synchrony, Diachrony" (PICANÇO, 2005), from the University of British Columbia. 
The paper is organized as follows. First, I provide an OT analysis of Mundurukú and Kuruaya's synchronic patterns, arguing for an approach in terms of the OCPsubsidiary feature effects (PADGETT, 1995), in which two features are critical to nasal harmony phenomena: [sonorant] and [voice]. Second, it is proposed that transparency and opacity are very similar properties, and do not require re-ranking of constraints. This is shown by the comparison of Mundurukú, a system with opacity, and Kuruaya, a system with transparency. These languages have the same ranking of constraints, with one crucial difference: the sequential prohibition *OraL NASAL (PULLEYBLANK, 2002) is locally defined in Mundurukú and non-locally in Kuruaya; but in both languages, the ranking is *OrAL NASAL » DерPAтн. Finally, the historical changes that gave rise to the system currently found in Mundurukú is outlined, arguing that they can be more adequately described in terms of constraint specialization, and that OT provides a good way to formalize the relative chronology of nasal harmony changes.

\section{Nasal harmony in the Mundurukú family: General aspects}

Mundurukú and Kuruaya are the only languages of the Mundurukú family (RODRIGUES, 1986). Both languages have nasal spread, but harmony is manifested in different ways. Mundurukú represents a case of regressive nasal assimilation where a nasal vowel spreads its [+nasal] feature to preceding [+sonorant] segments: vowels, nasals and approximants, /w, j, r, ?, h/, as illustrated in the following data. They show the participation of all sonorants, including laryngeals, /?, h/.

\begin{tabular}{|c|c|c|c|c|}
\hline (a) & /ərã/ & $\rightarrow$ & 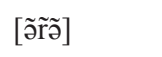 & 'maracanã bird' \\
\hline (b) & /waẽn/ & $\rightarrow$ & [w̃̃ãẽn] & 'oven' \\
\hline (c) & /wajõmpə/ & $\rightarrow$ & 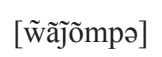 & ‘tipiti’ \\
\hline (d) & /wenã2ip/ & $\rightarrow$ & 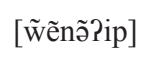 & 'Brazil nut tree' \\
\hline (e) & /wa?õ/ & $\rightarrow$ & 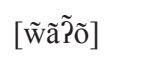 & 'my speech, language' \\
\hline (f) & /eõhõ/ & $\rightarrow$ & [ẽõhัõ] & 'your domestic animal' \\
\hline
\end{tabular}

Nasality is spread throughout an entire word, unless it encounters an obstruent (stop or fricative), which interrupts the process. This is shown by the examples below.

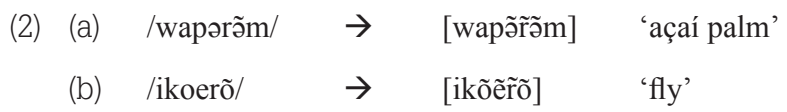



(C) /kadzarãw/ $\rightarrow \quad$ [kadzãrãã $] \quad$ 'a big pot'
(d) /weborõbə/ $\rightarrow$ [webõr̃̃öbə] 'my cotton string'
(e) $/$ posãy/ $\rightarrow$ [posə̃y] 'medicine'

Like Mundurukú, Kuruaya presents regressive nasalization within the word, and the trigger is also a nasal vowel. Unlike Mundurukú, nasalization targets not only [+sonorant] segments but also [+voiced] obstruents; voiceless obstruents are transparent. (3) illustrates assimilation by [+sonorant] segments; (4) illustrates assimilation by [+voiced] stops, in which case they surface as plain nasal consonants; and (5) illustrates transparency.

\begin{tabular}{|c|c|c|c|c|}
\hline (3) (a) & arĩt & $\rightarrow$ & [ãrit $]$ & 'anum (bird, sp.)' \\
\hline (b) & pawã & $\rightarrow$ & [pãw̃ã] & 'banana' \\
\hline (c) & welãĩ & $\rightarrow$ & [wẽẽããi] & 'Brazil nut' \\
\hline (a) & pobe-jã & $\rightarrow$ & [põmẽjã] & 'canoes' \\
\hline (b) & de-jã & $\rightarrow$ & [nẽjã] & 'they' \\
\hline (a) & w-e-aikõn & $\rightarrow$ & [w̃ẽãĩkõn] & 'my bench' \\
\hline (b) & parawa-tõ & $\rightarrow$ & [pãrããwãtõ] & 'macaw, sp.' \\
\hline (c) & warisõ & $\rightarrow$ & 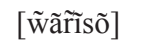 & 'bird, sp.' \\
\hline
\end{tabular}

Comparing Mundurukú and Kuruaya, the following similarities and differences are found:

(6)

\section{Trigger:}

Direction:

Segments affected:

Opaque segments:

Transparent segments: none
Kuruaya

rightmost nasal vowel right-to-left sonorants, voiced obstruents none voiceless obstruents

Comparative evidence suggests that nasal harmony in Mundurukú has been developed out of a system where segments were either transparent or targets, as in Kuruaya (PICANÇO, 2003). Both systems are similar with respect to triggers and direction of nasal harmony. They differ with respect to the participation of the various classes of segments in the phenomenon, and its local versus non- 
local nature. In Kuruaya, nasal harmony is not blocked; segments are targets or transparent. In Mundurukú, on the other hand, segments are targets or block spread. Kuruaya is also interesting because nasality affects segments that block the process in Mundurukú: the class of [+voiced] obstruents.

\section{Explaining the synchronic patterns}

In all nasal harmony surveys (e.g. WALKER, 2000; COHN, 1993; PIGGOTT, 1992; PULLEYBLANK, 1989), the general observation is that vowels show the strongest interaction with nasalization, whereas voiceless obstruents are typically neutral. Following vowels, we find glides, and then liquids. In the other extreme, we find obstruents (stops and fricatives), which often resist nasalization; yet, if they are targets in nasal harmony, the class of [+voiced] obstruents is more likely to be affected. Thus, vowels, glides and liquids comprise the class of segments that is most compatible with nasality, that of [+sonorant]; obstruents form the class of least compatibility with [+nasal]. The interplay between nasality and certain types of segments is schematized in (7).

(7) Compatibility with [nasal] (based on WALKER, 1998, 2000):

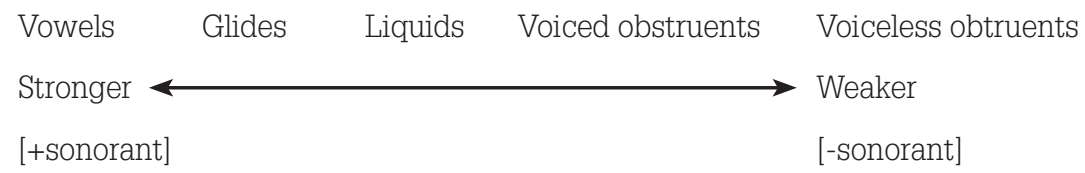

The [sonorant] feature can be used to distinguish two classes of segments in terms of compatibility with the [+nasal] feature: [+sonorant] is the most compatible, and [-sonorant] is the least compatible. This is represented here as the feature co-occurrence condition (PULLEYBLANK, 1989) defined in (8).

(8) Co-occurrence condition (PULLEYBLANK, 1989, p.109):

(i) If [+nasal] then [+sonorant]; or

(ii) If [+nasal] then not [-sonorant].

The co-occurrence condition is implemented here as a markedness constraint, NAS/SON.

(9) NAS/Son - If [+nasal] then [+sonorant].

In addition to [+sonorant], another feature that is compatible with [+nasal] is [+voice] (PULLEYBLANK, 1989). In systems where nasality is not blocked, voiceless 
obstruents behave transparently, and voiced obstruents typically participate in the process by assimilating the feature. There is an interesting relation here: like glides and liquids, voiced obstruents may undergo or block nasalization, but are hardly ever transparent. Voiceless obstruents, on the other hand, are either transparent or blockers, but not targets. In other words, in addition to [+sonorant], the [+voice] feature is what brings obstruents closer to the group of targets in nasal harmony. The interaction between [+nasal] and sonorants is expected to be the strongest, but voiced segments are also likely to be associated with the feature. Conversely, little interaction is expected with segments that are neither sonorants nor voiced, i.e. voiceless obstruents.

Another issue concerns harmony per se. Pulleyblank (2002; following SMOLENSKY, 1993) proposes deriving harmony by prohibiting feature disharmony ( ${ }^{*}$ F G). Pulleyblank's proposal unifies harmony with the Obligatory Contour Principle (OCP). Likewise, the OCP disallows sequences of identical elements, as well as feature disagreement.

(10) Sequential prohibition (PULLEYBLANK, 2002, p.253):

*X...Y: A sequence of $\mathrm{X}, \mathrm{Y}$ on a tier is prohibited.

Sequential prohibitions enforce adjacent segments to share the same value of a given feature. In the context of our discussion, the prohibition is on an oral + nasal sequence. The constraint proposed is *OraL NASAL (PULLEYBLANK, 2002, p.250), which evaluates segment-to-segment, irrespective of their compatibility with the [+nasal] feature.

(11) *Oral Nasal ( ${ }^{*}$ R Nas)

A [+nasal] segment may not be preceded by a [-nasal] segment.

To bring the hypothesis of harmony via no-disagreement even closer to the OCP-effects in Mundurukú and Kuruaya, *ORAL NASAL is instantiated as a constraint that is more strongly held between segments which share some additional features, also known as the OCP-subsidiary features effects (SUZUKI, 1998; PIERREHUMBERT, 1993; PADGETT, 1995; YIP, 1989; SELKIRK, 1988; MCCARTHY, 1986; MESTER, 1986). The idea is that *OraL NASAL enforces assimilation if adjacent segments share subsidiary features that are most compatible with [+nasal], as discussed earlier. These features are, according to the scale in (7) above, [+sonorant] and [+voiced]; languages may invoke one or both. For example, the set of targets in Mundurukú only includes [+sonorant] segments. They also share [+voiced], but this feature cannot be invoked because voiced stops are non-targets. Therefore, the OCP-subsidiary feature effect in Mundurukú states that two segments must 
agree for [+nasal] if they already share [+sonorant]. The revised version of the sequential prohibition *OraL NASAL is provided in (12).

(12) * Oral NASAL

A [+nasal] segment may not be preceded by a [-nasal] segment if they share the [+sonorant] feature.

To show *Oral Nasal effects, consider three sequences: stop + $\tilde{V}$ (e.g. bṼ), glide $+\tilde{\mathrm{V}}($ e.g. $w \tilde{\mathrm{V}})$, and nasal $+\tilde{\mathrm{V}}$ (e.g. $\mathrm{m} \tilde{\mathrm{V}}) .{ }^{*}$ OraL NASAL is violated in the [w $\left.\tilde{\mathrm{V}}\right]$ sequence because glides and vowels share the [+sonorant] feature, and this feature is compatible with [+nasal]; therefore, both must share [+nasal].

As far as the adjacency issue is concerned, proximity distinctions between trigger and target can be local - i.e. segment-to-segment: *ORAL-NASAL, or nonlocal - i.e. one or more segments may intervene between trigger and target: *Oral... Nasal. Suzuki (1998) proposes that proximity can be seen as the harmonic scale shown in (13), but a two-way distinction between local and non-local suffices for Mundurukú and Kuruaya's analyses.

(13) Proximity hierarchy (SUZUKI, 1998, p.82):

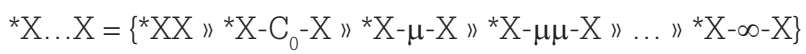

The local version of *OraL NASAL is as follows.

(14) *OraL-NASAL

A [+nasal] segment may not be immediately preceded by a [-nasal] segment if they share the [+sonorant] feature.

Contrary to Kuruaya, Mundurukú's [+nasal] propagation is from segment to segment, regarding that all segments are specified for the relevant feature.

\section{Synchronic OT analysis of nasal harmony in Mundurukú}

The hypothesis proposed in the account of nasal harmony in the Mundurukú family is that nasality targets specific groups of segments. Once this requirement is met, any extra feature association with a non-target is penalized. The constraint that penalizes associations deviating from the input is DePPATH (PULLEYBLANK, 1996), formulated here as DePPAтH[nasal]. Conversely, the constraint that prevents loss of [+nasal] associations is MAXPATH[nasal], given below; if [+nasal] is in the underlying representation of a segment, then it must also be present on the surface. 
(15) (a) MaxPath[nasal]

Any input path between [+nasal] and an anchor must have a correspondent path in the output.

(b) DepPath[nasal]

Any output path between [+nasal] and an anchor must have a correspondent path in the input.

In general, segments that are targets to the harmonic feature necessarily violate DepPATH[nasal]; but once this requirement has been met, any other association will be fatal. The ranking is given in (16). Please remember that NAs/ Son is an alternative to distinguish a class of segments that is most compatible with nasality.

(16) Mundurukú's ranking:

MaxPath[nas], Nas/Son » *Or-Nas » DepPath[nas]

With this ranking, for vowels that are underlyingly assigned to [nasal], harmony is obligatory if the adjacent segments are also [+sonorant]. The following tableau illustrates nasality propagation. In a sequence formed only by sonorants, the ranking MaXPath[nas], NAS/Son » *OR-NAS » DePPATH[nas] determines that nasality be shared by all sonorants in the sequence.

\section{Tableau 1 - Nasal propagation in a sequence of

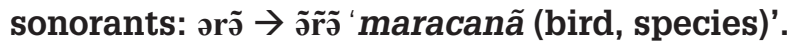

\begin{tabular}{|c|c|c|c|c|}
\hline ərã & $\begin{array}{c}\text { MaX } \\
\text { Path[nas] }\end{array}$ & NAS/SON & *OR-NAS & $\begin{array}{c}\text { Dep } \\
\text { Path[nas] }\end{array}$ \\
\hline 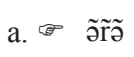 & & & & $* *$ \\
\hline b. ərว̃ & & & $* !$ & \\
\hline c. әrə & *! & & & \\
\hline
\end{tabular}

Source: Prepared by the author (see also PICANÇO, 2005, p.230).

The next tableau illustrates opacity. Once all sonorants in a sequence have been associated with the [+nasal] feature, ${ }^{*} \mathrm{OR}-\mathrm{NAS}$ is met. From this point on, any association of the harmonic feature counts as a fatal violation of DePPATH[nas]. This constraint is necessarily violated, but violations are tolerated only to satisfy the high-ranking status of *Or-NAS. When a [+nasal] feature reaches a non-target, nasality propagation must be interrupted. This is the reason why candidate (b) loses, and (c) wins. Note also that DepPATH[nas] treats multiply linked features and 
insertion of features similarly. Even if we assume that the [+nasal] feature skips the stop in a form such as candidate (b), it would also be excluded by DePPAтн[nas].

\section{Tableau 2 - Opacity with voiceless obstruents: ikoerõ $\rightarrow$ ikõẽẽ̃̃ 'fly’.}

\begin{tabular}{|c|c|c|c|c|}
\hline ikoerõ & $\begin{array}{c}\text { MaX } \\
\text { РАTH[nas] }\end{array}$ & NAS/Son & *OR-NAS & $\begin{array}{c}\text { DeP } \\
\text { Path[nas }]\end{array}$ \\
\hline a. $\quad \tilde{1}^{1} k$ kõẽõ & & *! & & $* * * * *$ \\
\hline b. 1 ikõẽ̃̃̃ & & & & $* * * * !$ \\
\hline c. ikõẽ r̃õ & & & & $* * *$ \\
\hline d. ikoerõ & & & *! & \\
\hline e. ikoero & $* !$ & & & \\
\hline
\end{tabular}

Source: Prepared by the author (see also PICANÇO, 2005, p.231).

Amongst obstruents, voiced stops are also compatible with nasality; but in Mundurukú, they block nasal spread.

\section{Tableau 3 - Opacity with voiced obstruents: borõ $\rightarrow$ bõ r̃õ 'cotton plant'.}

\begin{tabular}{|c|c|c|c|c|}
\hline borõ & $\begin{array}{c}\text { Max } \\
\text { Path[nas }]\end{array}$ & NAS/Son & *OR-NAS & $\begin{array}{c}\text { DeP } \\
\text { PATH[nas] }\end{array}$ \\
\hline a. bõ $\tilde{r}^{0}$ & & & & $* *$ \\
\hline b. mõ ${ }^{\tilde{r}} \tilde{}$ & & & & $* * * !$ \\
\hline c. borõ & & & *! & \\
\hline
\end{tabular}

Source: Prepared by the author (see also PICANÇO, 2005, p.231).

In nasal harmony, laryngeals / $\mathrm{h}, \mathrm{h} /$ are also targets. Since nasal spread in Mundurukú is crucially one of feature compatibility, in which [+sonorant] plays a central role, laryngeals do not pose a problem because they fall into this group (see CHOMSKY; HALLE, 1968). In Mundurukú, /h/ phonetic shape is determined by context (PICANÇO, 2005); as such, it seems plausible to assume that it is also compatible with nasalization. In fact, Ohala (1974, p.364) observes that "[...] the position of the velum during glottal and pharyngeal consonants must be largely 
contextually determined." Glottis closure blocks both oral and nasal airflow, but this interruption provides no indication about the velum position - whether it is lowered or elevated. If segments are defined as amenable to nasalization, as those articulatorily compatible with a lowered velum, laryngeals offer no counterevidence to this hypothesis.

Overall, Mundurukú's laryngeals can be assumed to be compatible with a lowered velum, especially because they are largely dependent on the contexts in which they occur (PICANÇO, 2005). Therefore, /?, h/ participation in nasal harmony is not surprising. It is also assumed that they are specified for the [+consonantal, +sonorant] features. The tableau below illustrates nasality in a V?Ṽ sequence. The wã?̃ output follows the ranking if we assume that, phonologically, laryngeals are [+sonorant], and as such, they are also targets to nasal propagation.

\section{Tableau 4 - Nasal propagation through laryngeals.}

\begin{tabular}{|c|c|c|c|c|}
\hline wa?õ & $\begin{array}{c}\text { Max } \\
\text { Path[nas] }\end{array}$ & NAS/SON & *OR-NAS & $\begin{array}{c}\text { Dep } \\
\text { PAth[nas] }\end{array}$ \\
\hline 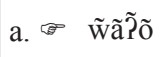 & & & & $* * *$ \\
\hline b. wa?õ & & & *! & \\
\hline
\end{tabular}

Source: Prepared by the author (see also PICANÇO, 2005, p.236).

To sum up, nasal harmony can be seen as a sub-case of the OCP-subsidiary features' effects, in that the more similar trigger and target are, the stronger their interaction. It was suggested that harmony is enforced in a string of segments if they all share the subsidiary feature [+sonorant].

Moreover, opacity can be seen as the association of the harmonic feature in a segment-to-segment basis, as long as they are all compatible with it. Incompatibility results in interruption of the process. Once the harmony constraint is satisfied, every new association is fatal, as predicted by the *OraL-NASAL " DерPAтH[nas] ranking.

\section{Synchronic OT analysis of nasal harmony in Kuruaya}

To account for nasal harmony in Kuruaya, two sequential prohibitions are suggested below. One for [+sonorant], (17); and another for [+voice], (18). Stipulation of these two features as two separate subsidiary features accounts for the change in nasal harmony, to be examined later. Since voiceless obstruents are transparent, *ORAL NASAL is crucially non-local. 
(17) *OrAL... NASAL ${ }_{\text {son }}$ (non-local version)

In a string of $\mathrm{s}_{n} \ldots \mathrm{S}_{2}, \mathrm{~s}_{1}$ segments, if $\mathrm{s}_{2}$ precedes $\mathrm{s}_{1}, \mathrm{~s}_{n}$ precedes $\mathrm{s}_{2}$, and $\mathrm{s}_{2}, \mathrm{~s}_{n}$ are [+sonorant, \pm syllabic], but $\mathrm{s}_{1}$ is [+sonorant, +syllabic, +nasal], then $\mathrm{s}_{2}, \mathrm{~s}_{n}$ must also be [+nasal].

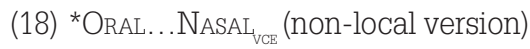

In a string of segments $\mathrm{S}_{n} \ldots \mathrm{S}_{2}, \mathrm{~s}_{1}$, if $\mathrm{s}_{2}$ precedes $\mathrm{s}_{1}, \mathrm{~s}_{n}$ precedes $\mathrm{s}_{2}$, and $\mathrm{s}_{2}, \mathrm{~s}_{n}$ are [+voice, \pm syllabic], but $\mathrm{S}_{1}$ is [+voice, +syllabic, +nasal], then $\mathrm{s}_{2}, \mathrm{~s}_{n}$ must also be [+nasal].

The tableau below shows assimilation in a sequence of sonorants. Note that the ranking suggested to Kuruaya is similar to that suggested to Mundurukú, except for the *OraL... NASAL ${ }_{\mathrm{vcB}}$ constraint, which is absent in Mundurukú.

\section{Tableau 5 - Assimilation by sonorants: pawã $\rightarrow$ pã w̃ã 'banana'.}

\begin{tabular}{|c|c|c|c|c|c|}
\hline pawã & $\begin{array}{c}\text { MAx } \\
\text { PATH[nas] }\end{array}$ & NAS/SON & $*$ Or...NAS & $*$ Or...NAS & $\begin{array}{c}\text { DEP } \\
\text { PATH[nas] }\end{array}$ \\
\hline a. pãwã & & & & $* *$ & $* *$ \\
\hline b. pawã & & & $* ! *$ & $* *$ & \\
\hline c. mãwã & & & & & $* * !$ \\
\hline
\end{tabular}

Source: Prepared by the author (see also PICANÇO, 2005, p.249).

Another interesting prediction concerns opacity versus transparency. As previously discussed, standard OT accounts for opacity cases by ranking faithfulness constraints, particularly DEP - higher than the harmony constraint; transparency, on the other hand, requires DeP to be low ranked (e.g. PULLEYBLANK, 2002). It is necessary that Dep be ranked lower in Kuruaya, the transparency case. However, in the proposition offered here, opacity and transparency follow from the same principle, namely that associations with the harmonic feature are tolerated only in order to meet the harmony constraint; this satisfaction is local in Mundurukú and non-local in Kuruaya. Tableau 6 provides an example. Voiceless obstruents are not targets, as they are neither [+sonorant] nor [+voice], but nothing prevents them from assimilating nasality and surfacing as plain nasal stops, e.g. candidate (d). However, the only associations that may violate DерPAтн[nas] are the ones required by the high-ranking sequential prohibitions, which favor candidate (a). 
Tableau 6 - Transparency of voiceless segments:

parawa-tõ $\rightarrow$ pã̃̃ã̃̃ãã 'macaw, sp.'

\begin{tabular}{|c|c|c|c|c|c|}
\hline parawa-tõ & $\begin{array}{c}\text { MaX } \\
\text { PATH[nas] }\end{array}$ & NAS/SON & *OR....NAS & *OR...NAS VAE $_{\text {VE }}$ & $\begin{array}{c}\text { DeP } \\
\text { PATH[nas }]\end{array}$ \\
\hline a. pãrãũãtõ & & & & & $* * * * *$ \\
\hline b. parawatõ & & & $* ! * * * *$ & $* * * * *$ & \\
\hline c. pãrãw̃ã̃̃̃ & & $* !$ & & & \\
\hline d. pãr̃ãwãnõ & & & & & $* * * * * * !$ \\
\hline
\end{tabular}

Source: Prepared by the author (see also PICANÇO, 2005, p.250).

The next tableau shows assimilation of voiced stops. *OR... NAS vor demands that, in a sequence of segments, if they all agree for [+voice], than they must all agree for [+nasal]. Even though an output, such as põbẽ ja a, candidate (a), satisfies ${ }^{*} \mathrm{OR}_{\mathrm{R}} . . \mathrm{NAS}_{\mathrm{SON}}$, it violates ${ }^{*} \mathrm{OR} \ldots \mathrm{NAS}_{\text {vor }}$, because /b/ is [+voice].

Tableau 7 - Assimilation with voiced stops: pobe-jã $\rightarrow$ põmẽjã 'canoes'.

\begin{tabular}{|c|c|c|c|c|c|}
\hline pobe-jã & $\begin{array}{c}\text { MaX } \\
\text { РАтн[nas] }\end{array}$ & NAS/SON & *OR...NAS ${ }_{\text {SON }}$ & $* \mathrm{OR} \ldots \mathrm{NAS}_{\mathrm{VCE}}$ & $\begin{array}{c}\text { DeP } \\
\text { PATH[nas }]\end{array}$ \\
\hline a. põbẽ jã & & & & $* !$ & $* * *$ \\
\hline 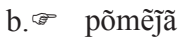 & & & & & $* * * *$ \\
\hline c. pobẽjãã & & & $* !$ & $*$ & $* *$ \\
\hline
\end{tabular}

Source: Prepared by the author (see also PICANÇO, 2005, p.250).

Having suggested the analyses of nasal harmony in Mundurukú and Kuruaya, a historical approach to the phenomenon is now taken, suggesting an OT account of the changes that Mundurukú has undergone, and demonstrating how the language acquired the present system.

\section{An OT account of a historical change in nasal harmony}

In this section, nasal harmony is approached from a historical point of view to show that historical data and language change can directly bear the 
OT assessment. This study deals with different reconstruction levels: ProtoMundurukú, which compares Mundurukú to its sister-language, Kuruaya; and Pre-Mundurukú, which refers to an earlier stage of Mundurukú only. In some cases, we also need to refer to Pre-Proto-Mundurukú, a stage preceding ProtoMundurukú. As a convention, reconstructed forms will be marked with an asterisk “*”; forms without asterisks are synchronic.

Picanço (2010) examines in detail all nasal harmony changes in the Mundurukú family. She shows that the source system, Proto-Mundurukú, had similar properties to those observed in Kuruaya. Particularly, (i) targets were voiced stops and sonorants; and (ii) voiceless obstruents were transparent. From Pre-Mundurukú until the modern period, nasal harmony was developed into another system, turning obstruents into opaque segments, thus blocking nasalization. This diachronic scenario is outlined below:

(19) The four historical nasal harmony changes in Mundurukú (PICANÇO, 2010, p.251)

i. Harmony changed from non-local to local; consequently,

ii. the system changed from a transparent segments one to another with opaque segments.

iii. The set of targets was reduced to sonorants; consequently,

iv. voiced stops became non-targets.

These changes are illustrated in (20) and (21). From Pre-Proto-Mundurukú until Proto-Mundurukú, nasality affected all voiced segments, and skipped voiceless obstruents. This nasal spread pattern changed when voiced stops were reanalyzed as phonemes in Proto-Mundurukú, creating new contrasts in the language, especially between oral voiced and nasal stops (23)c; yet, these contrasts are still neutralized in harmonic contexts because nasality targets both sonorants and voiced obstruents.

(20)

\begin{tabular}{|c|c|c|c|}
\hline Pre-Proto-Mundurukú & & Proto-Mundurukú & \\
\hline *Loa [Loa] & $>$ & $*$ Loa $[\mathrm{Loa}]$ & 'spider' \\
\hline *Lõy［L̃̃on] & $>$ & *Lõy [L̃̃o] & 'flea' \\
\hline 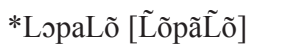 & $>$ & 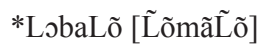 & 'gun, rifle' \\
\hline *Lapãn [L̃ãpãn] & $>$ & *Lapãn [L̃ãpãn] & 'to run/escape' \\
\hline
\end{tabular}

From Proto-Mundurukú until Pre-Mundurukú, *L developed into *d, carrying two allophones along: [d] in oral context and [n] in nasal context. 
(21)

\begin{tabular}{|c|c|c|c|}
\hline Proto-Mundurukú & & Pre-Mundurukú & \\
\hline *Loa [Loa] & $>$ & $*$ doa [doa] & 'spider' \\
\hline *Lõy [L̃̃on] & $>$ & *dõy [nõy] & 'flea' \\
\hline *LobaLõ [L̃õmãL̃̃̃] & $>$ & *dobadõ [nõmãnõ] & 'gun, rifle' \\
\hline *Lapãn [L̃ãpãn] & $>$ & *dapãn [nãpãn] & 'to run/escape' \\
\hline
\end{tabular}

Introduction of voiced obstruents $\left({ }^{*} b,{ }^{*} d\right)$ between Pre-Proto-Mundurukú and Proto-Mundurukú established new contrasts, especially between oral voiced and nasal stops, but these were neutralized in harmonic contexts. Nasality thus obscures the new consonant inventory. In order to avoid this, speakers need to enhance the way voiced oral stops are pronounced in harmonic contexts, preventing nasality from spreading through them. Perceptually, having nasality in both sides of [b] in a [ṽbṽ] sequence is not as effective as having nasality on only one side, i.e. [vbṽ]. A new rule emerges, prohibiting the co-occurrence of [+nasal] with [-sonorant] segments altogether.

We shall now consider how OT components contribute to our understanding of phonological reanalysis and language change. Changes (i) and (ii), given in (19) above, can be explained by the following historical change in the sequential prohibition: *OraL. . . NASAL changed to *ORAL-NASAL, meaning that nasal harmony became more restricted; i.e. the non-local requirement became strictly local. As for (iii) and (iv), these changes can be explained by a change in the ranking itself:

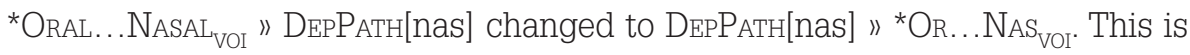
illustrated by the proto-Mundurukú word *LobaLõ 'rifle, gun', shown in Tableau 8. The (non-local) sequential prohibitions required that all [+sonorant] and [+voiced] segments also be [+nasal] if the last vowel was [+nasal]; thus candidate (b) was the optimal output at that stage.

Tableau 8 - Proto-Mundurukú: *LobaLõ 'rifle, gun'

\begin{tabular}{|c|c|c|c|c|c|}
\hline *LobaLõ & $\begin{array}{c}\text { MaX } \\
\text { PATH[nas }]\end{array}$ & NAS/SON & $*$ Or.... NAS ${ }_{\text {SON }}$ & $* \mathrm{OR}_{\ldots} . . \mathrm{NAS}_{\mathrm{VCE}}$ & $\begin{array}{c}\text { DeP } \\
\text { Path[nas }]\end{array}$ \\
\hline a. $\quad$ L̃õbãL̃̃ & & & & $* !$ & $* * * *$ \\
\hline b. ${ }^{\mp}$ L̃mã̃̃̃̃ & & & & & $* * * * *$ \\
\hline c. LobãL̃õ & & & $* ! *$ & $* * *$ & $* *$ \\
\hline
\end{tabular}

Source: Prepared by the author (see also PICANÇO, 2005, p.251). 
From Proto-Mundurukú until Pre-Mundurukú, the proto-phoneme ${ }^{*} \mathrm{~L}$ developed into *d, so *LobaLõ became *dobadõ; since nasal harmony remained as in the proto-language, *d was [d] in oral contexts and [n] in nasal contexts, as shown in the following tableau. The optimal output was [nõmãnõ], in which all sonorants and voiced stops surface nasal.

Tableau 9 - Pre-Mundurukú: *dobadõ 'rifle, gun'

\begin{tabular}{|c|c|c|c|c|c|}
\hline *dobadõ & $\begin{array}{c}\text { MaX } \\
\text { PATH[nas] }\end{array}$ & Nas/Son & *OR....NAS SON & *OR...NAS & $\begin{array}{c}\text { DeP } \\
\text { Path[nas] }\end{array}$ \\
\hline a. dõbãdõ & & & & $* ! * *$ & $* *$ \\
\hline b. nõmãnõ & & & & & $* * * * *$ \\
\hline c. dobãnõ & & & $* !$ & $* *$ & $* *$ \\
\hline d. dobadõ & & & $* ! *$ & $* * *$ & \\
\hline e. nobãnõ & & & $* !$ & * & $* *$ \\
\hline
\end{tabular}

Source: Prepared by the author (see also PICANÇO, 2005, p.252).

Several changes took place between Pre-Mundurukú and the modern stage, as schematized in (22). First, harmony became strictly local; this can be interpreted as a change in the constraint: *OR...NAS > *OR-NAS (i.e. non-local > local). Second, the allophones of ${ }^{*} \mathrm{~d},[\mathrm{~d}] /[\mathrm{n}]$, became independent (secondary split): ${ }^{*} \mathrm{~d}>\mathrm{d} / \mathrm{n}$; in OT, phonologization can be achieved by faithfulness to allophones - e.g. MAX-[d] and MAX-[n]. Finally, voiced stops have developed into opaque segments; this suggests that ${ }^{*} \mathrm{OR}_{\mathrm{R}} \mathrm{NAS}_{\mathrm{VOI}}$ lost its importance in the language, and consequently, its

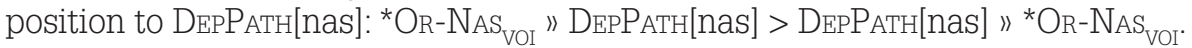
For reasons which will be clarified later, ${ }^{*} \mathrm{OR}-\mathrm{NAS}_{\mathrm{VOI}}$ did not simply lose its position to DерРАтн[nas]; it is suggested that this constraint was completely lost, and this was regardless of DePPath[nas].

(22) From Pre-Mundurukú to Mundurukú ( $\mathrm{NH}$ = nasal harmony)

\begin{tabular}{|c|c|}
\hline $\begin{array}{l}\text { Pre-Mundurukú } \\
\text { NH (not blocked) } \\
\text { 000NH (blocked) }\end{array}$ & 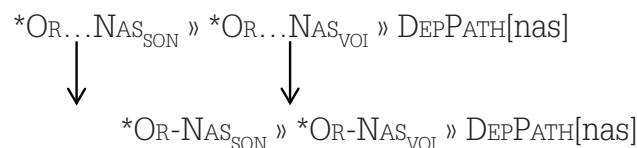 \\
\hline Secondary split & $\operatorname{MAX}-[\mathrm{n}], \operatorname{MAX}-[\mathrm{d}] \quad\llcorner$ \\
\hline Mundurukú & 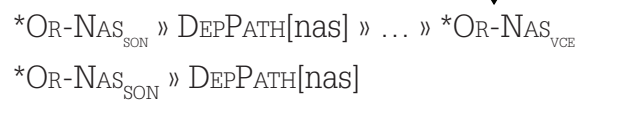 \\
\hline & Contrast between /d/ and /n/ \\
\hline
\end{tabular}


As complex as these changes may seem, an OT analysis can be suggested. To begin with, please recall from Tableau 9 above that the output for the word *dobadõ in Pre-Mundurukú was [nõmãnõ], in which [nasal] was associated with every segment in the word. Take this output to be our "input" for the next stage (modern Mundurukú), as shown in Tableau 10. Note that this proposal differs from the OT assumption that changes involve constraint re-ranking. Here, constraints are also allowed to become more restrictive, without changing their ranking position. Additionally, the tableau does not represent a synchronic stage in particular, but the historical changes that gave rise to the modern system. It is meant to provide the relative chronology of the historical changes schematized in (22), including some immediate grammar consequences. Each column represents the order of these developments, and columns separated by dotted lines indicate simultaneous developments.

Finally, in the [nõmãnõ] "input", the [nasal] feature appears linked to every segment, but this is because [nõmãnõ] was the surface form prior to the changes, and not because they were all specified for this feature. The source is the last vowel in the morpheme; preceding segments are targets. (See below for further comments on this tableau).

\section{Tableau 10 - An OT relative chronology for nasal harmony changes.}

\begin{tabular}{|c|c|c|c|c|c|}
\hline $\begin{array}{c}\text { *[nõmãnõ] } \\
\text { [nas] }\end{array}$ & $\begin{array}{l}\text { MAX-/b/ } \\
\text { MAX-/m/ }\end{array}$ & $\begin{array}{l}\text { *OR...NAS } \text { SON }_{\mathrm{SON}} \\
>* \text { OR-NAS } \\
\text { SON }\end{array}$ & $\begin{array}{l}\mathbf{I} * \mathrm{OR} \ldots \mathrm{NAS}_{\mathrm{VCE}} \\
\mathbf{1}>* \text { OR-NAS } \\
\mathbf{I}_{\mathrm{VCE}}\end{array}$ & $\begin{array}{l}\operatorname{MAX}-[\mathrm{n}] \\
\operatorname{MAX}-[\mathrm{d}]\end{array}$ & $\begin{array}{l}\text { DEP } \\
\text { PATH[nas] }\end{array}$ \\
\hline $\begin{array}{l}\text { a. กõmãnõ } \\
\text { [nas] }\end{array}$ & *! & & I & & $* * * * *$ \\
\hline b. nobãnõ & & & I & & $* * *$ \\
\hline 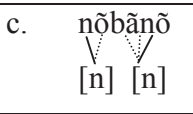 & & & $\begin{array}{l}1 \\
1 \\
1 \\
1\end{array}$ & & $* * * * !$ \\
\hline $\begin{array}{c}\text { d. dobãnõ } \\
\text { [n] }\end{array}$ & & & 1 & $* !$ & $* *$ \\
\hline
\end{tabular}

Source: Prepared by the author (see also PICANÇO, 2005, p.253).

When the system changed from transparency to opacity (i.e. *OR. . NAS $>$ *ORNAS), the phonemic inventory had to be restructured with respect to the values to be assigned to nasal allophones, since the change caused environment loss that conditioned the allophonic variations $[\mathrm{b}] /[\mathrm{m}]$. The faithfulness constraints MAX-/b/ and $\mathrm{MAX}-/ \mathrm{m} /$ preserved the contrast in the following stage, and this is the reason 
it is ranked above the change. It follows from this that, when the change in nasal harmony took place, the "output" could no longer assign [m] to the underlying representation of [nõmãnõ]; the nasal variant [m] had already been associated with the phoneme /b/. This is why candidate (a) is ruled out.

As for [d] and [n], it was established earlier that they were * $d$ allophones, and developed out of the ${ }^{*} \mathrm{~L}>{ }^{*} \mathrm{~d}$ change; they only became independent later as a result of the change in the non-local character of nasal harmony: ${ }^{*}$ OR...NAS > ${ }^{*}$ OR-NAs. This change had a consequence in the inventory. By restricting nasal harmony to a locality requirement, the conditioning environment for the [d]/[n] alternation was lost in many cases, and the inventory needed be restructured with respect to the underlying representations for these allophones. By Lexicon Optimization (PRINCE; SMOLENSKY, 1993), represented in the tableau by the faithfulness constraints MAX-[d] and MAX-[n], inputs should mirror their outputs. For example, candidate (d) is excluded because the phoneme / $d /$ is assigned to the allophone [n] in the context where nasality was lost. However, the "input" has the allophone [n], so the form /d/ in that context fatally violates MAX-[n].

At this point, two candidates remain. Candidate (b) locally spreads the harmonic feature, as now demanded by the sequential prohibition *Or-NAS; and candidate (c) spreads the feature from both a nasal vowel and a nasal consonant, fatally violating DepPath[nas]. The change in ranking, * $\mathrm{OR}_{\mathrm{R}} \mathrm{NAS}_{\mathrm{voI}}$ " $\mathrm{DepPATH}[\mathrm{nas}]$ $>$ DePPATH[nas] " ${ }^{*} \mathrm{Or}-\mathrm{NAS}_{\mathrm{VoI}}$, took place after these changes, as a consequence of contrast preservation between $/ \mathrm{b} /$ and $/ \mathrm{m} /$ everywhere, and [d] and [n] phonologization, which militated against the requirement that voiced obstruents should be nasal in nasal contexts. In other words, the sequential prohibition ${ }^{*} \mathrm{OR}-\mathrm{NAS}_{\mathrm{VOI}}$ became unnecessary, losing its importance in the language. This is why Mundurukú only needs the ranking *OR-NAS ${ }_{\text {SON }}$ " DePPATH[nas]. This gives us the 'optimal system': nasality locally spreads to [+sonorant] segments, and is blocked by [-sonorant].

\section{Conclusion}

This paper has provided an OT analysis of Mundurukú and Kuruaya's synchronic nasalization systems, in addition to an OT account of the historical changes that gave rise to the system presently found in Mundurukú. The hypothesis is that every change in one area entails deterioration somewhere else in the system by causing the emergence of new patterns (KIPARSKY, 1982). In the case at stake, emergence of new contrasts in Mundurukú entailed a change in nasal harmony. Restructuring of the system may itself imply a new change, but this is not necessarily related to constraint re-ranking, as it has been advocated by standard OT approaches. Two related grammars may have the same ranking, but different applications of the related constraints. 
PICANÇO, G. Teoria da otimalidade e fonologia histórica: um exemplo da harmonia nasal em mundurukú. Alfa, São Paulo, v.57, n.1, p.257-274, 2013.

- RESUMO: Este trabalho pretende mostrar que a Teoria da Otimidade proporciona novas formas para explicar mudanças de som que não a re-ordenação no ranqueamento deconstraints. Ele examina os aspectos diacrônicos de harmonia nasal na família Mundurukú, tronco Tupi. A comparação entre os sistemas modernos de Mundurukú e Kuruaya salienta que o sistema original, Proto-Mundurukú, tem propriedades semelhantes às atualmente observadas em Kuruaya. Em especial, os alvos do espalhamento de nasalidadeincluiamoclusivas sonoras e soantes, enquanto que as obstruintes surdas eram transparentes. Esse sistema evoluiu para outro em Pré-Munduruku, quando novos contrastes foram introduzidos na língua, transformando obstruintes em segmentos opacos e, portanto, bloqueando a nasalização. A análise, formalizada dentro da Teoria da Otimidade, demonstra que não houve uma reordenação dos constraints harmônicos; eles apenas se tornaram mais restritos, como mostra a cronologia relativa que deu origem ao sistema moderno de Mundurukú. Além disso, o estudo discute também as consequências dessa mudança para a gramática sincrônica, e como isso explica as irregularidades do processo.

- PALAVRAS-CHAVE: Mudança de som. Harmonia nasal. Teoria da Otimidade. Fonologia diacrônica. Mundurukú.

\section{REFERÊNCIAS}

CHOMSKY, N.; HALLE, M. The sound pattern of english. New York: Harper \& Row, 1968.

COHN, A. A survey of the phonology of the feature [ \pm nasal]. Working Papers of the Cornell Phonetics Laboratory, Ithaca, v.8, p.141-203, 1993.

KIPARSKY, P. Explanation in phonology. Dordrecht: Foris Publications, 1982.

MCCARTHY, J. OCP effects: gemination and antigemination. Linguistic Inquiry, Cambridge, v.17, p.207-264, 1986.

MCCARTHY, J.; PRINCE, A. Prosodic morphology I: constraint interaction and satisfaction. 1993. Technical Report 3. Available in: <http://roa.rutgers.edu/ files/482-1201/482-1201-MCCARTHY-0-0.PDF>. Access in: 23 nov. 2007.

MESTER,A. Studies in tier structure. 1986. 263f. Thesis (Doctoral in Linguistics) University of Massachusetts, Amherst, 1986.

OHALA, J. J. Experimental historical phonology. In: ANDERSON, J. M.; JONES, C. (Ed.). Historical linguistics II: theory and description in phonology. Amsterdam: North Holland, 1974. p.353-389.

PADGETT, J. Stricture in feature geometry. Stanford: CSLI Publications, 1995.

PICANÇO, G. A reconstruction of nasal harmony in Proto-Mundurukú. International Journal of American Linguistics, Chicago, v.76, n.4, p.411-438, 2010. 
Mundurukú: phonetics, phonology, synchrony, diachrony. 2005. $424 \mathrm{f}$. Thesis (Doctoral in Linguistics) - University of British Columiba, Vancouver, 2005. Comparando harmonia nasal em Mundurukú e Kuruaya. 2003. Paper presented at the VII Jornada de Estudos Linguísticos e Literários, Belém, 2003.

PIERREHUMBERT, J. Dissimilarity in the Arabic verbal root. NELS, Amherst, v.23, p.367-381, 1993.

PIGGOTT, G. Variability in feature dependency: the case of nasality. Natural Language and Linguistic Theory, Netherlands, n.10, p.33-78, 1992.

PRINCE, A.; SMOLENSKY, P. Optimality theory. constraint interaction in generative grammar. 1993. Technical Report 2. Available in: <http://roa.rutgers.edu> Access in: 30 nov. 2007.

PULLEYBLANK, D. Harmony drivers: no disagreement allowed. In: ANNUAL MEETING OF THE BLS, 28., 2002, Berkeley. Proceedings... Berkeley: Berkeley Linguistics Society, 2002. p.249-267.

Neutral vowels in optimality theory: a comparison of yoruba and wolof. Canadian Journal of Linguistics, Toronto, v.41, p.295-347, 1996.

Patterns of feature cooccurrence: the case of nasality. Coyote Papers, Tucson, n.9, p.98-115, 1989.

RODRIGUES, A. D. Línguas brasileiras: para o conhecimento das línguas indígenas. São Paulo: Loyola, 1986.

SELKIRK, E. Dependency, place, and the notion 'tier'. 1998. Paper presented at the annual meeting of the LSA, New Orleans, 1988.

SMOLENSKY, P. Harmony, markedness and phonological activity. 1993. Paper presented at the Rutgers Optimality Workshop, New Brunswick, 1993.

SUZUKI, K. A. Typological investigation of dissimilation. 1998. 221f. Thesis (Doctoral in Linguistics) - University of Arizona, Tucson, 1998.

WALKER, R. Nasalization, neutral segments, and opacity effects. 1998. 150f. Thesis (Doctoral in Linguistics) - University of California, Santa Cruz, 1998.

_. Nasalization, neutral segments, and opacity effects. New York: Garland, 2000.

YIP, M. Feature geometry and co-occurrence restrictions. Phonology, Cambridge, v.6, n.2, p.349-374, 1989.

Recebido em 02 de outubro de 2010

Aprovado em 24 de novembro de 2012 